\title{
IDENTIFYING THE BARRIERS TO AFFIRMATIVE ACTION TRAINING: Perceptions of AfFirmative aCtion APPOINTEes IN MpUMAlanga PUBliC HOSPITAlS
}

Authors:

Edward Rankhumise

Fulufhelo G. Netswera ${ }^{2}$

\section{Affiliations:}

${ }^{1}$ Department of

Management and

Entrepreneurship, Tshwane

University of Technology,

Pretoria, South Africa

${ }^{2}$ Research Directorate, University of South Africa (UNISA), Pretoria,

South Africa

\section{Correspondence to:}

Edward Rankhumise

email:

rankhumiseem@tut.ac.za

\section{Postal address:}

Department of Management and Entrepreneurship,

Tshwane University of

Technology, Private bag

X680, Pretoria 0001, South

Africa

\section{Keywords:}

AA; discrimination; equal opportunities; mentoring; training interventions

\section{Dates:}

Received: 19 May 2009

Accepted: 24 Aug. 2010

Published: 16 Nov. 2010

How to cite this article:

Rankhumise, E., \&

Netswera, F.G. (2010).

Identifying the barriers to affirmative action training: Perceptions of affirmative action appointees in Mpumalanga public hospitals. SA Journal of

Human Resource

Management / SA Tydskrif vir Menslikehulpbronbestuur $8(1)$, Art. \#222, 6 pages. DOI: 10.4102/sajhrm.v8i1.222

This article is available at:

http://www.sajhrm.co.za

(c) 2010. The Authors. Licensee: OpenJournals Publishing. This work is licensed under the Creative Commons Attribution License.

\begin{abstract}
Orientation: Since the advent of democracy in 1994 numerous policies and programmes were put in place to address the imbalances of race and gender in the South African labour force.

Research purpose: The aim of this study is to gauge the perceptions about existing barriers in the implementation of affirmative action (AA) training interventions at public hospitals in the Mpumalanga Province.
\end{abstract}

Motivations for the study: The research conducted in this study provides valuable information which would enable the Mpumalanga health department and public hospital management to develop improved interventions associated with AA training interventions.

Research design, approach and method: The population of the study consists of two groups of participants which are AA appointees and AA mentors. The study mixed qualitative and quantitative research methodological processes.

Main findings: Results of this study show that there are differences in perceptions between Black respondents who believe that mentors should be held liable for the failure of the mentees and White respondents who disagreed. The findings suggest that employees are of the opinion that internal policy guidelines on the implementation of AA are not communicated to all employees.

Practical implications: Public hospital management should articulate the purpose of AA interventions and its targets to both mentors and mentees and continuously review the implementation thereof.

Contribution: The study contributes towards explaining the importance of training interventions that are useful for the success of AA appointees in their respective duties and also give account of barriers that are experienced by these appointees.

\section{INTRODUCTION}

Since 1994, efforts taken to address the imbalances associated with race and gender in South Africa's workforce are specifically those that relate to legislative reforms as well as training and mentoring for affirmative action (AA) appointees. This article explores the existing barriers found in AA mentoring programmes, as perceived by AA appointees in Mpumalanga public hospitals. A combined qualitative and quantitative research approach was followed in researching this topical issue. The research findings reveal that there are remaining barriers in terms of AA candidates not functioning efficiently, which AA training has not managed to address. One such barrier is perceived to be the resistance of appointed mentors to provide training; this perception has been expressed mainly by Black AA appointees, whereas White female AA appointees have argued that no such barrier exists. Conclusions drawn from the findings include the following, (1) implementing AA requires guiding policies at institutional level, (2) various support mechanisms, beyond AA training, are required by the beneficiaries of AA and (3) the appointed mentors' resistance to providing training must be explored.

South Africans embarked on a major transformation in the workplace environment after democratisation took place in 1994. The introduction of different legislative reforms aimed at eliminating discrimination and promoting equal opportunities in the workplace featured prominently in the Employment Equity Act 55 of 1998 and in the Skills Development Act 97 of 1998. These policy initiatives are amongst the various corrective measures undertaken by government to advance historically marginalised groupings, such as Black and female workers, in an attempt to reverse the imbalances experienced under apartheid rule.

Kahlenberg (1996, p. 6) and Du Plessis (1995, p. 85) perceive the apartheid legacy as being responsible for the concentration of Black people in lower-level positions in the workplace. In implementing corrective measures for this problem, the South African government opted to review all discriminatory legislation and afford all employees equal opportunities. In terms of the Employment Equity Act of 1998, the previously disadvantaged groups in the South African context are Black people (African, Indian and Coloured people), women of all races and people with disabilities.

The implementation of the Employment Equity Act puts pressure on all government departments to ensure that their staff complement is demographically reflective and representative of all sections of the South African population (Republic of South Africa, 1998c, section 15B). The successful 
implementation of AA requires well-guided mentoring and training interventions. According to Herholdt and Marx (1999, p. 6), training interventions are about mentoring, on-the-job training and routine work schedule clarification. These training interventions are a determinant of either success or failure (Human, 1993, p. 13). Greeff and $\mathrm{Nel}$ (2003, p. 24) and Wingrove (1993, p. 153) view the lack of success in terms of AA as the result of limited time and attention dedicated to the acceleration of on-the-job training. While the National Department of Public Service and Administration provides policy guidelines on how $\mathrm{AA}$ and employment equity (EE) should be implemented, the implementing departments are able to refine these guidelines to suit their situation (Republic of South Africa, 1998a).

To complement this requirement, the Department of Health provided hospitals with its policy on the implementation of AA and EE thereby simplifying implementation processes within the department. For training interventions in the Mpumalanga Department of Health, the mentoring programme has been selected as an appropriate intervention. According to Wingrove (1993, p. 163), such a methodology could have negative effects if there are perceived threats that the persons being mentored could in future take the mentors' positions. The White mentors, in particular, see the mentoring programme as a way to replace them after they have provided a successful mentoring process by giving them early retirement. Popular opinions are already being documented, specifying that the increasing skills development of Black people could cause the retrenchment of White people, which results in reverse discrimination (Basit \& McNamara, 2004, p. 101; Wingrove, 1993). The programmes of AA must therefore be implemented carefully if reverse discrimination is to be prevented (Barker, 2007, p. 248). If there are any perceptions of reverse discrimination, which could hamper the development of Black employees, it could affect the success of cross-cultural integration and the implementation of training interventions.

In terms of section 2 of the Skills Development Act of 1998 (Republic of South Africa, 1998b), government departments should ensure that AA is reinforced through training intervention measures in order to provide AA candidates with the opportunity to acquire new skills. Any obstacles standing in the way of training interventions have to be addressed in accordance with the internal policy of the organisation concerned and such a policy should address resistance to change, EE and skills development plans (Esterhuyse, 2003, p. 5; Wingrove, 1993, p. 65). The success of the AA programme depends on, amongst other things, on-the-job training and the willingness of the trainers and trainees to participate.

Considering the need for labour force and workplace transformation and the challenges in implementing transformative instruments like AA and mentoring training interventions, this study aims to articulate perceptions about existing barriers in terms of the implementation of AA training in Mpumalanga public hospitals. Owing to the racial polarisation of South African society, it can therefore be hypothesised that the perception of the success of AA mentoring differs along racial lines. In order to achieve these set goals, a set of research processes were followed to execute the actual research.

\section{RESEARCH DESIGN}

\section{Research approach}

A two-phase design, referred to as the triangulation of research methods, was used for this study, which combined qualitative and quantitative methods (Denzin \& Lincoln, 2000). Creswell (1994, p. 177) regards the use of the two methods as advantageous because it enables the researcher(s) to present the paradigm assumptions that are not tenable with only one method. The use of triangulation enabled the researchers to collect adequate data. Qualitative data is used to illustrate or clarify quantitatively derived findings with more clarity rather than a purely statistical presentation. The two methods are therefore complementary (Strauss \& Corbin, 1990, p. 19).

\section{Research strategy}

Both qualitative and quantitative strategies were employed. In this case, surveys were used in conjunction with semi structured interviews.

\section{Qualitative methods sought}

Prior to conducting the research, permission was requested and obtained from the Chief Director of the Hospital Services of the Mpumalanga public hospitals. A total of ten AA training mentors were purposefully sampled, with their names being provided by various hospital administration departments. A consent form was attached to the invitation extended to the mentors for participation in interviews. In these letters, participants were promised anonymity and confidentiality in terms of sensitive information linking them directly with the research outcomes (Polit \& Beck, 2004, p. 291). An interview guide was developed from literature, including the EE and AA policy and strategy documents. Taped interviews were transcribed and analysed using Tesch's data reduction method, as outlined by Creswell (1994, p. 155). The findings from qualitative discussions with participants are presented verbatim; in other words, only the major themes and statements that repeat themselves throughout the discussions are discussed as 'emerging themes'.

\section{Quantitative survey}

This survey followed from the qualitative study. Data from the qualitative study as well as the literature were combined for the development of this survey questionnaire. A sample of 205 respondents from 15 Mpumalanga public hospitals was selected to participate in the research, using systematic sampling methodology from the various lists that were provided by the hospitals' administration departments. The focus was on the former Transvaal Provincial Administration (TPA) hospitals, which were administered by White people and provided fertile ground for probing transformation processes. The survey questionnaire yielded two types of data sets, namely those of a biographical nature and mainly closed responses to Likertscale AA statements (Bless \& Higson-Smith, 1995, p. 121). This quantitative data was analysed at an inferential statistical level with computation of chi-square tests (hypothesis testing) to check for variations in perceptions of the success or failure of the AA programmes.

\section{Research participants}

The population of the study consisted of AA appointees and mentors in the Mpumalanga public hospitals. In terms of the lists provided by the hospitals' administrations, the fifteen hospitals surveyed had a total of 205 AA appointees with the questionnaires distributed to all of them. From the distributed 205 questionnaires in the 15 hospitals, a total of 108 questionnaires were returned fully completed, constituting a 53\% response rate. This response rate is deemed acceptable for generalisation purposes (Sarantakos, 1997, p. 158). The returned questionnaires were from the following hospitals: Philadelphia (7), Groblersdal (17), Middelburg (1), Witbank (0), Sabie (6), Lydenburg (10), Bernice Samuel (3), Themba (2), Rob Ferreira (10), Barberton (13), Carolina (6), Bethal (9), Ermelo (4), Standerton (12) and Evander (6). It was only at Witbank hospital that not a single questionnaire was returned. In terms of the racial composition of the ten mentors interviewed, seven were African people and three were White people. Most of the mentors were not willing to take part in the study and referred the researchers to the chief executive officers of the respective hospitals. Before presenting the various hypotheses, it is important to indicate that the overall respondent base in this survey comprised $26.9 \%$ males and $73.1 \%$ females, with a racial make-up of $72.2 \%$ African respondents, $24.1 \%$ White 
respondents and only 3.8\% Coloured respondents. From the 108 questionnaires analysed, $61(56.5 \%)$ respondents were in the administrative staff category, 34 (31.5\%) were in nursing, 3 $(2.8 \%)$ were doctors and $10(9.3 \%)$ were allied health workers. It is notable from the analysis that most of the staff at the hospitals surveyed was in the administrative category (56.5\%). The reason for this could be that it is easier to implement AA amongst administrative appointees than it is in other staff categories. The second-most represented category was nursing, accounting for $31.5 \%$ and was as a result of various divisional responsibilities attached to the wards and nursing administration. From the research, it is evident that only 10 mentors took part in the study. Most of the mentors were not willing to take part and it was also not possible to interview mentors in other hospitals.

\section{DISCUSSION}

The findings of the quantitative study are structured to test the various assumptions (i.e. hypothesis tests) that are made in terms of variables that may influence perceptions about the effectiveness of AA mentoring programmes. Such variables include race, language, educational level and position within the organisation. However, findings from qualitative interviews are quoted verbatim. These are themes that emerged throughout most of the interviews and are therefore deemed 'general trends'. The implementation of a verbatim record of the interviews allows the researchers to augment the qualitative presentations and vise versa without altering the original statements from the respondents.

Language is one of the variables that is instrumental in the formation of associations and prejudices (Rankhumise, 2007, p. 141). It is therefore appropriate to presume that such a variable has the potential to create perceptions about AA relationships. More importantly, these may not only be perceptions, but rather evident daily realities between beneficiaries of AA appointments and their appointed mentors. The findings of this research reveal a Pearson chi-square test result of 0.004 which suggests that there are indeed significant differences in how respondents of different language groups perceive the willingness of mentors to provide AA mentoring to their appointed mentees. The Swati- and Zulu-speaking respondents recognised that those occupying senior positions were resistant to providing mentorship to AA appointees. English- and
Afrikaans-speaking respondents, on the other hand, did not identify any resistance to the provision of AA mentorship by the mentors.

\section{Race-based affirmative action perceptions}

Testing for differences in perceptions on at least four statements across racial lines revealed significant differences. In all these statements, the differences which were tested using Pearson chi-square test values, all yielded a $(P=0.00)$, suggesting very strong differences between the perceptions of Black and White respondents' perceptions. While Black respondents thought that mentors should be held responsible for the failure of their mentees, White respondents disagreed:

.... As a mentor I do not think I should entirely be held responsible for the failure of the mentee, this is a twofold issue ... There should be agreement between the two parties and where shortcomings are experienced that should be sorted out ...'

Interestingly, these respondents differed even on matters such as whether or not internal hospital policies existed on how the implementation of AA should be handled. Mentors attested as follows:

'There are internal policies within the hospitals; the challenge is whether staff members are conversant on how such policies are applied ... Quite often policies are circulated to all departments in the hospitals and if a person has no interest in a policy, it will just be kept in a file and when asked about the availability of such policies, the answer is we do not have a policy ...'

Black respondents were of the opinion that the hospitals had no such internal policies while their White colleagues stated that such policies existed. This sentiment was supported by qualitative analysis:

'There are plans for general training not specifically for $A A$... ... AA is taking place but there is no statistics or evidence to say these are employees appointed on the basis of $A A$...'

Black respondents thought that there was resistance to train AA appointees by those holding higher positions, whereas their White colleagues disagreed. A close inspection of these findings suggests that Black respondents are aggrieved and therefore have negative perceptions about their White colleagues and about the AA process in general. Such perceptions are partly fuelled by further perceptions that White colleagues in higher positions preside over and determine the success of mentoring processes (Rankhumise, Netswera \& Meyer, 2001). These

TABLE 1

Race-based affirmative action perceptions

\begin{tabular}{|c|c|c|c|c|c|c|c|}
\hline \multirow[t]{2}{*}{ Statement } & \multicolumn{2}{|c|}{ African respondents } & \multicolumn{2}{|c|}{ Coloured respondents } & \multicolumn{2}{|c|}{ White respondents } & \multirow[t]{2}{*}{ Chi square } \\
\hline & Agree & Disagree & Agree & Disagree & Agree & Disagree & \\
\hline $\begin{array}{l}\text { Mentors should be held responsible for the } \\
\text { failure of the persons mentored by them. }\end{array}$ & $41.50 \%$ & $18.80 \%$ & - & $2.80 \%$ & $2.80 \%$ & $13.20 \%$ & 0.000 \\
\hline $\begin{array}{l}\text { The hospital has an internal policy on } \\
\text { how to implement AA. }\end{array}$ & $25.00 \%$ & $30.50 \%$ & $0.90 \%$ & $1.80 \%$ & $0.90 \%$ & $3.70 \%$ & 0.004 \\
\hline $\begin{array}{l}\text { There is resistance by those holding } \\
\text { higher positions to train AA appointees. }\end{array}$ & $39.00 \%$ & $10.10 \%$ & - & $0.90 \%$ & - & $8.30 \%$ & 0.000 \\
\hline $\begin{array}{l}\text { Historical educational disadvantages have } \\
\text { resulted in Black employees being less capable } \\
\text { than White employees in the work situation. }\end{array}$ & $47.60 \%$ & $13.00 \%$ & - & $2.80 \%$ & $1.80 \%$ & $8.40 \%$ & 0.000 \\
\hline
\end{tabular}

k situation.

AA, affirmative action.

TABLE 2

Education-based affirmative action perceptions

\begin{tabular}{|c|c|c|c|c|c|c|c|c|c|c|c|}
\hline \multirow[t]{2}{*}{ Statement } & \multicolumn{2}{|c|}{ Grade 12 or < } & \multicolumn{2}{|c|}{ Post-matric certificate } & \multicolumn{2}{|c|}{ Diploma } & \multicolumn{2}{|c|}{ Degree } & \multicolumn{2}{|c|}{ Postgraduate degree } & \multirow[t]{2}{*}{ Chi square } \\
\hline & Agree & Disagree & Agree & Disagree & Agree & Disagree & Agree & Disagree & Agree & Disagree & \\
\hline $\begin{array}{l}\text { Mentors should be held } \\
\text { responsible for the failure of the } \\
\text { persons mentored by them. }\end{array}$ & $20.00 \%$ & $11.30 \%$ & $6.70 \%$ & $5.70 \%$ & $8.60 \%$ & $6.70 \%$ & $3.70 \%$ & $10.30 \%$ & $5.70 \%$ & $0.90 \%$ & 0.004 \\
\hline $\begin{array}{l}\text { AA will fail if it is not supported } \\
\text { by training interventions. }\end{array}$ & $31.40 \%$ & - & $12.90 \%$ & - & $14.80 \%$ & $2.70 \%$ & $18.50 \%$ & - & $6.40 \%$ & - & 0.003 \\
\hline $\begin{array}{l}\text { AA training interventions will } \\
\text { fail if they are not funded. }\end{array}$ & $30.50 \%$ & $0.90 \%$ & $9.20 \%$ & $1.80 \%$ & $13.90 \%$ & $1.80 \%$ & $12.90 \%$ & $2.70 \%$ & $3.70 \%$ & $2.70 \%$ & 0.005 \\
\hline
\end{tabular}


findings strengthen the assumption that choosing one's own mentor or mentee, rather than getting one appointed for you involuntarily, could be the best way to overcome these negative perceptions. Thomas and Robertshaw (1999) also regard the establishment of a good mentoring relationship and smooth running of mentoring processes to be dependent on good relationships between the two parties involved. Their findings confirm that the parties involved in the mentoring process are committed to ensuring its success only if they are familiar with each other. This will enable both parties to deem the process mutually beneficial.

These findings confirm the findings by Rankhumise (2007,p. 116) namely that because of historical and educational inferiorities and disadvantages, Black employees are more likely to receive AA mentoring. AA mentoring, therefore, is a racially charged process whereby Black employees are automatically mentees and White employees are mentors, resulting in perpetual and often non-verbalised antagonism and polarised perceptions about the efficiency and effectiveness of the mentoring process. AA training and mentoring is a restorative justice process that is aimed at correcting workforce imbalances created during apartheid rule; therefore, in this process, Black employees feel maltreated (Rankhumise, Netswera \& Meyer 2001, p. 43).

\section{Education-based AA perceptions}

In terms of section 20(3) of the Employment Equity Act of 1998, a person may be suitably qualified as a result of different criteria namely (1) formal qualifications, prior learning, relevant experience and capacity to acquire a qualification within a stipulated time frame and (2) the ability to do the job. In line with these stipulations, one other important question to ask in this type of analysis is: What effect does an educational or academic qualification have on perceptions about the effectiveness of AA programmes across race lines? The Pearson chi-square test results obtained from the three statements suggest significant differences on the basis of educational levels of the various respondents. Respondents with a Grade 12 qualification or less $(20 \%)$ felt that mentors should be held responsible for the failure of the persons being mentored $(P=0.04)$. Interviewed mentors did not concur with the AA appointees, namely that they were resisting training them:

'Yes, as mentors It seems as if we are resisting training $A A$ particular those without post-matric qualifications. The problems we encounter is that this category requires more intensive mentoring [than] the other categories ...'

However, the majority of those respondents with diplomas and degrees had a different perception. The results further indicate that respondents with Grade 12 or less (31.4\%) believed that AA will fail if it is not supported by training interventions. It was only those respondents who held a postgraduate diploma or degree that seemed confident that AA mentoring can succeed without major interventions.
White employees are performing better than African employees because the latter were not afforded education and training opportunities during the apartheid era. It is for this historical reason that black employees in the work situation are generally employed in non-decision making positions such as administration clerks, gardeners and cleaners. The findings correlate positively with the reference in the Industrial Conciliation Act of 1924, which stated that through segregation, racial privileges were afforded to White people, providing the foundation for the policy of job reservation on the basis of race resulting in racial discrimination. Furthermore, the findings are in line with references in the Black Building Workers Act of 1951 and with Finnemore (1999) and Bendix (2001) that Black employees were prohibited from performing high-skilled jobs and that certain skilled jobs were reserved for White employees. The majority of these imbalances are a result of the Industria Conciliation Act, which was passed as AA that guaranteed positions for White employees only.

\section{Perceptions based on organisational sections}

The hospital setup has four major demarcations, namely administration, nursing, medical and the allied health section. The formation of perceptions in these various sections of the hospitals regarding AA mentoring seems to vary significantly at a Pearson chi-square test value of 0.001. Employees in these various sections differed significantly on whether or not AA developmental programmes are available in the hospital. The administrative, nursing, medical and allied health workers believed there were developmental programmes available in the hospitals that were intended for them. However, a small number of medical staff and a higher number of administrators thought differently. The stipulation in the Employment Equity Act of 1998 and in the White Paper on AA (Republic of South Africa, 1998a, section 3.22) specifies that employers (i.e. hospitals) must prepare EE plans which will achieve reasonable progress towards EE in the workforce. According to these policies, this process must include (1) the analysis of the numerical goals required to achieve equitable representation of suitably qualified people from designated groups, (2) the timetable within which this is to be accomplished and (3) the strategies to be used.

\section{Perceptions based on employment levels}

The self-selection and pairing of mentors and mentees on the basis of familiarity and mutual interest in each other's development have historically been found to be central to the success of mentoring processes (Thomas \& Robertshaw, 1999; Rankhumise, Netswera \& Meyer, 2001). These perceptions were tested amongst employees at various employment levels and, according to the findings, significant differences in perceptions

TABLE 3

Perceptions based on organisational sections

\begin{tabular}{|c|c|c|c|c|c|c|c|c|c|}
\hline \multirow[t]{2}{*}{ Statement } & \multicolumn{2}{|c|}{ Administration } & \multicolumn{2}{|c|}{ Nursing } & \multicolumn{2}{|c|}{ Medical } & \multicolumn{2}{|c|}{ Allied health } & \multirow[t]{2}{*}{ Chi square } \\
\hline & Agree & Disagree & Agree & Disagree & Agree & Disagree & Agree & Disagree & \\
\hline $\begin{array}{l}\text { Developmental programmes are } \\
\text { available in the hospital. }\end{array}$ & $30.80 \%$ & $17.70 \%$ & $20.50 \%$ & $5.60 \%$ & $0.90 \%$ & $1.80 \%$ & $2.80 \%$ & - & 0.001 \\
\hline
\end{tabular}

TABLE 4

Perceptions based on employment levels

\begin{tabular}{|c|c|c|c|c|c|c|c|c|c|}
\hline \multirow[t]{2}{*}{ Statement } & \multicolumn{2}{|c|}{ Top management } & \multicolumn{2}{|c|}{ Middle management } & \multicolumn{2}{|c|}{ First level } & \multicolumn{2}{|c|}{ Operational } & \multirow[t]{2}{*}{ Chi square } \\
\hline & Agree & Disagree & Agree & Disagree & Agree & Disagree & Agree & Disagree & \\
\hline $\begin{array}{l}\text { If mentees appoint their own } \\
\text { mentor, the mentoring } \\
\text { process is likely to succeed. }\end{array}$ & $4.90 \%$ & - & $5.90 \%$ & $15.80 \%$ & $12.90 \%$ & $5.90 \%$ & $25.00 \%$ & $9.90 \%$ & 0.004 \\
\hline $\begin{array}{l}\text { There is a policy available } \\
\text { to monitor and evaluate the } \\
\text { success of training } \\
\text { interventions. }\end{array}$ & $0.90 \%$ & $3.90 \%$ & $8.70 \%$ & $13.60 \%$ & $2.90 \%$ & $5.80 \%$ & $12.60 \%$ & $7.80 \%$ & 0.003 \\
\hline
\end{tabular}


were found amongst employees at different employment or management levels. While employees at top, first and operational level agreed that if a person who is being mentored appoints their own mentor, the mentoring is likely to succeed; middle management level employees differed significantly at a Pearson chi-square test value of 0.004. Employees also differed significantly in terms of their perceptions of whether a policy existed which would enable them to mentor and evaluate the success of training interventions. Those who differed significantly $(P=0.03)$ were employees at top and operational level. These findings suggest that the introduction of the policy was not communicated to all levels of management throughout these hospitals. It is imperative that any policy that affects the entire workforce be communicated and top management should preferably ensure that all staff members are sensitised to the policy. Policy intervention intends to achieve basic understanding and support for AA appointees and can only be implemented if the intended parties are familiar with its content.

\section{CONCLUSION}

This study examines the sentiments of the AA appointees in terms of the hurdles that they encounter while carrying out their respective duties. From the policy perspective of AA, the implementation of such policies should be supported through training interventions to ensure that beneficiaries of AA training become successful. The support is imperative in the sense that those who were previously disadvantaged should be fast-tracked through the necessary training support interventions. The article argues that because there are still hurdles associated with the implementation of AA training interventions, certain measures need to be put in place in order to address these difficulties and ensure that AA appointees perform at expected levels. The findings on which this article is based, suggest that barriers in terms of the implementation of training interventions remain in existence and include the following:

- There is a perceived resistance by those holding senior positions to training AA appointees and providing the necessary mentoring support.

- There are perceptions that internal policies on the implementation of AA and development plans are available, but it seems these policies are not communicated to all employees.

- AA employees feel that if funding is not provided, the efforts in AA interventions are likely to fail.

- The historical educational disadvantages of Black employees have caused Black employees to be less capable in the area of high-skilled jobs when compared to their White counterparts.

- Mentors attested that where AA practices are in place, good cooperation exists between hospital management, employees and trade unions. As a result, employees become motivated in the execution of their duties.

In order to address the identified barriers, the following recommendations are suggested:

- The implementation of AA should be followed by effective training interventions.

- For the mentoring process to succeed the management of the hospitals should make mentors responsible for the failure of the persons they mentor; mentoring should therefore have measurable success factors.

- Consultations with employees in terms of the communication of policies are currently perceived as being inadequate; this should be corrected to effect a common understanding of policies and their objectives.

- Employees with lower educational levels require increased mentoring and training support than other AA employees; interventions should therefore be tailor-made to address these differences amongst AA beneficiaries.

- AA beneficiaries of Black descent, in comparison with those from other racial groups, are more concerned about their mentorship and training experiences. In an effort to make AA training interventions equally accessible to all, the hospital management should identify any obstacles in terms of equal access and equal benefits.

- Hospitals should embark on AA practices supported by training interventions because the implementation thereof could improve the performance of the employees in the respective hospitals.

It is imperative to sensitise hospital managers and AA beneficiaries to the importance of implementing AA policies and strategies within the various hospitals so that an understanding of the basic principles associated with these interventions is embraced by all. Management of hospitals should ensure that an environment is cultivated for the establishment of a positive relationship between mentor and mentee. This can be achieved by objectively selecting mentors and mentees, rather than imposing selections on the parties. When allowing mentees to choose their own mentors, careful consideration should be given to the selection processes to avoid subjectiveness that may compromise the achievement of positive mentoring outcomes and experiences.

There are several limitations in this study that have a bearing on the results. Firstly, the study was conducted in Mpumalanga public hospitals and, as a result, the researchers are unable to claim any generalisation of the findings. Secondly, because participation explicitly emphasised voluntary participation, it can be that there may have been some differences in responses with those who did not choose to participate. Due to financial constraints, it was not possible to cover all the hospitals in the Mpumalanga Province. Finally, another study could be important on a broader scale, preferably in other provinces, with the intention of exploring further findings and to discuss experiences of AA appointees in diverse settings.

This study provides valuable information which would enable hospital management to develop internal policies regarding the implementation of AA. This could assist in resolving some of the identified hurdles encountered by AA appointees. If AA appointees fail in the execution of their duties, the AA process could be regarded as futile. Therefore the necessary support mechanisms should be provided to ensure that all AA beneficiaries succeed in fulfilling their duties.

\section{REFERENCES}

Barker, F. (2007). The South African Labour Market: Theory and Practice. (5th edn.). Pretoria: Van Schaik.

Basit, T.N., \& McNamara, O. (2004) Equal Opportunities or Affirmative Action? The Induction of Minority Ethnic Teachers. Journal of Education for Teaching, 30(2) 101-102.

Bendix, S. (2001). Industrial Relations in South Africa. (4th edn.). Lansdowne: Juta.

Bless, C., \& Higson-Smith, C. (1995). Fundamentals of Social Research Methods. An African Perspective. (2nd edn.). Kenwyn: Juta.

Creswell, J.W. (1994). Research Design. Qualitative and Quantitative Approaches. California: Sage.

Denzin, N.K., \& Lincoln, Y.S. (eds.) (2000). Handbook of Qualitative Research. (2nd edn.). Thousand Oaks: Sage.

Du Plessis, K.R. (1995). Perceptions Concerning the Effects of Affirmative Action on Productivity in Local Government. MA dissertation. Johannesburg: University of the Witwatersrand.

Esterhuyse, W.P. (2003). The Challenges of Transformation: Breaking the Barriers. South African Journal of Business Management, 34(3), 1-8.

Finnemore, M. (1999). Introduction to Labour Relations in South Africa. (7th edn.). Durban: Butterworths.

Greef, A., \& Nel, P. (2003). Employment Transformation Enhancement in South Africa: Establishing a Job-sharing Model to Promote Employment Equity. South African Journal of Labour Relations, 27(2), 23-62. 
Herholdt, W., \& Marx, M. (1999). Employment Equity in South Africa: A Guide to Affirmative Action Success. South Africa: Prentice Hall.

Human, L.N. (1993). Affirmative Action and the Development of People: A Practical Guide. Kenwyn: Juta.

Kahlenberg, R.D. (1996). The Remedy: Class, Race, and Affirmative Action. New York: BasicBooks.

Martins, N., \& Von der Ohe, H. (2003). Organisational Climate Measurement - New and Emerging Dimensions during a Period of Transformation. South African Journal of Labour Relations, 27(3), 41-58.

Munetsi, W. (1999). Affirmative Action - A Simplistic View. People Dynamics, 17(1), 36.

Polit, D.S., \& Beck, C.T. (2004). Nursing Research: Principles and Methods. (7th edn.). Philadelphia: Lippincott.

Rankhumise, E.M. (2007). The Effectiveness of Training Interventions Implemented by Mpumalanga Public Hospitals. Doctoral thesis. Pretoria: Tshwane University of Technology.

Rankhumise, E.M., Netswera, G., \& Meyer, M. (2001). Employees' Perceptions of the Implementation of Affirmative Action in the Health Sector in the Standerton District in South Africa. Curationis, 24(4), 54-57.
Republic of South Africa. (1924). Industrial Conciliation Act 11 of 1924. Pretoria: Government Printer.

Republic of South Africa. (1951). Black Building Workers Act 27 of 1951. Pretoria: Government Printer.

Republic of South Africa. (1998a). White Paper on Affirmative Action. Pretoria: Government Printer.

Republic of South Africa. (1998b). Skills Development Act 97 of 1998. Pretoria: Government Printer.

Republic of South Africa. (1998c). Employment Equity Act 55 of 1998. Pretoria: Government Printer.

Sarantakos, S. (1997). Social Research. Basingstoke: Palgrave.

Strauss, A., \& Corbin, J. (1990). Basics of Qualitative Research. Grounded Theory Procedures and Techniques. California: Sage.

Thomas, A., \& Robertshaw, D. (1999). Achieving Employment Equity: A Guide to Effective Strategies: Developing the Fabric of Organisations. Randburg: Knowledge Resources.

Wingrove, T. (1993). Affirmative Action. A 'How to' Guide for Managers. Randburg: Knowledge Resources. 